\title{
Embryonic development of the degu, Octodon degus
}

\author{
Mariana A. Rojas, M. A. Montenegro and B. Morales \\ Department of Experimental Morphology, University of Chile Medical School, Casilla 2988, \\ Correo Central, Santiago, Chile
}

\begin{abstract}
Summary. Although the degu has a long gestation period $(87 \pm 3$ days $)$ the pattern of development from mating to birth is similar to that of other rodents. However, each of the basic processes occurs more slowly than in myomorph rodents and the degu could therefore be useful for studies on embryonic development.
\end{abstract}

\section{Introduction}

The degu (Octodon degus; Family Octodontidae; Suborder Caviomorpha; Order Rodentia), sometimes also called the trumpet-tail mouse or mouse of the pircas (see Osgood, 1943), is one of the most common wild animals of the central region of Chile $\left(28-58^{\circ} \mathrm{S}\right.$ and $0-1800 \mathrm{~m}$ above sea level: Tamayo \& Frassinetti, 1980), where the predominant vegetation is a matorral, an evergreen sclerophyllous scrub. The principal types of plants consist of a few basic life forms: evergreen sclerophyllous shrubs and trees such as Acacia caven, Muhlembeckia hastulata: drought-deciduous shrubs such as Trevoa trinervos and succulents (Montenegro, Hoffmann, Aljaro \& Hoffmann, 1979).

In the wild, the animals are diurnal (Yañez \& Jaksic, 1978) and are probably seasonal breeders (Contreras \& Bustos, 1977; Rojas, Rivera, Montenegro \& Barros, 1977).

There is a period of sexual inactivity from January until June (summer and autumn) and mating occurs between the end of June and early July (beginning of winter), coinciding with the shorter daylengths. The first parturitions mostly occur in September-October (spring) with second litters being born in December (summer), but a small number of females give birth in October and November (Rojas et al., 1977).

Degu $(200-300 \mathrm{~g})$ adapt easily and rapidly to laboratory conditions (Weir, 1970). As in other caviomorphs there is a vaginal closure membrane which becomes perforate at the start of the mating period (Weir, 1974). Copulation takes place during the first 2 days of vaginal opening (Weir, 1974) and the gestation period is 90 days (range 87-93 days: Weir, 1974). The litter size is $1-10$ (mean 5 ) and puberty occurs $2-9$ months after birth.

In recent years, the degu has been studied in the laboratory and the observations on gonadal morphology (Weir \& Rowlands, 1974), differentiation (Morales \& Leyton, 1977: Potocnjak \& Bustos-Obregón, 1977; Morales, Leyton \& Rojas, 1978) and reproductive physiology (Montenegro, Bustos, Berríos \& Barros, 1977; Berrios, Flechón \& Barros, 1978; Contreras \& Bustos-Obregón, 1980) suggest that it could be useful laboratory animal for descriptive and experimental studies. Some embryological data have been given by Roberts (1971) and Roberts \& Perry (1974) but the aim of the present paper was a precise study of embryonic development.

\section{Materials and Methods}

Females born in captivity were maintained under conditions of controlled temperature $\left(20-22^{\circ} \mathrm{C}\right)$ and with natural light. Food and water were available ad libitum. During the period 
of reproductive activity (June-July) females with a perforated vaginal membrane were placed with selected males, and vaginal smears were taken every morning. When spermatozoa were found in the smear, the female was removed and the day was considered as Day 0 of pregnancy. Some females were isolated from the male after 3 days of pairing.

Females were killed by cervical dislocation at different times of pregnancy. The oviduct and the uterus were perfused with Brinster's solution (Brinster, 1971) to recover pre-implantation embryos. Early post-implantation embryos were fixed for $2 \mathrm{~h}$ in a $6 \%$ glutaraldehyde solution in $0.1 \mathrm{M}$-phosphate buffer, post-fixed for $30 \mathrm{~min}$ in $2 \%$ osmium tetroxide in phosphate buffer, dehydrated in ethanol and embedded in Epon epoxy resin. Serial sections ( $1 \mu \mathrm{m}$ thick) were stained with basic toluidine blue. Some early post-implantation stages were fixed within the uterus in Bouin's fluid, dehydrated, embedded in paraffin wax, serially sectioned at $6 \mu \mathrm{m}$ and stained with haematoxylin and eosin.

More advanced embryos were dissected out under saline solution, were weighed in a precision balance and the crown-rump length was measured with a vernier caliper. The most advanced member of each litter was considered to represent the development standard for that gestational age (Scott, 1937). The embryos were examined macroscopically to evaluate the external morphology and then were fixed in Bouin's fluid, dehydrated, embedded in paraffin wax, serially sectioned at $6 \mu \mathrm{m}$ in frontal, sagittal and transverse planes. The sections were stained with haematoxylin and eosin or by the periodic acid-Schiff (PAS) technique.

\section{Results}

In our colony the gestation period was 84-90 days and characteristics of embryonic development at different stages are shown in Table 1. Five periods of development could be recognized; they were marked by implantation, first somite, disappearance of anterior somites and appearance of characteristic octodontid features.

\section{Pre-implantation development}

By $12 \mathrm{~h}$ after finding spermatozoa in the vaginal smear (time 0), all the eggs with loosely attached corona cells were found in the oviduct. About $24 \mathrm{~h}$ the eggs contained two pronuclei and all of them had protruded the second polar body. One pronucleus was larger and contained more nucleoli than the other (Pl. 1, Fig. 1).

The 2-cell stage lasted about $48 \mathrm{~h}$ and 2 -cell eggs were recovered only from the oviduct. The first cleavage resulted in blastomeres of almost equal size and spermatozoa were not seen in the perivitelline space (Pl. 1, Fig. 2).

Early morula stages ( $8-12$ blastomeres) were observed in the uterus by $72 \mathrm{~h}$ (Pl. 1, Fig. 3).

At the blastocyst stage, from $4 \frac{1}{2}$ days, the embryos were present in the uterus.

\section{Early post-implantation development}

Implantation began antimesometrially at $6 \frac{1}{2}-7$ days and was of the interstitial type. Up to this time, the blastocyst was spherical; the inner cell mass protruded into the blastocoele cavity. There was a decidual cell reaction where the blastocyst was in contact with the uterine epithelium but disruption of the epithelial cells was not observed (Pl. 1, Fig. 4).

A new uterine lumen was formed in the endometrium. The lumen of the uterus and the uterine epithelium disappeared. The endoderm differentiated and formed a distinct single cell layer applied to the inner cell mass. At 9-10 days post coitum (p.c.) the blastocyst began to elongate. The amniotic cavity appeared as a small cleft in the centre of the embryoblast at $12-13$ days p.c. (PI. 1, Figs 5 and 6). 
Table 1. Developmental stages in degu embryos

\begin{tabular}{|c|c|c|c|c|c|c|}
\hline \multirow{2}{*}{$\begin{array}{l}\text { No. of } \\
\text { animals }\end{array}$} & \multicolumn{2}{|c|}{ Age } & \multicolumn{2}{|c|}{ Length } & \multirow{2}{*}{$\begin{array}{l}\text { Weight } \\
\text { (mg) }\end{array}$} & \multirow[b]{2}{*}{ Main external features } \\
\hline & Days* & Hours $\dagger$ & $\mu \mathrm{m}$ & $\mathrm{mm}$ & & \\
\hline 5 & & $12-24$ & 60 & & & Zygote with pronuclei \\
\hline 5 & & $24-80$ & 60 & & & Cleavage \\
\hline 2 & & $105-110$ & $90-100$ & & & Blastocyst \\
\hline 3 & & $156-168$ & & & & Implantation begins \\
\hline 3 & $12-14$ & & & & & Amniotic cavity; bilaminar embryo \\
\hline 4 & $20-21$ & & & $0 \cdot 8$ & & Primitive streak; trilaminar embryo \\
\hline 4 & $24-26$ & & & $2 \cdot 0$ & & 4-5 somites; neural groove; allantoic bud \\
\hline 5 & $27-28$ & & & $2 \cdot 5-3 \cdot 5$ & $1 \cdot 2-4 \cdot 4$ & $\begin{array}{l}\text { C-shape embryo; } 20 \text { somites; heart } \\
\text { prominence visible; two branchial } \\
\text { arches; ear placodes and eye cups } \\
\text { present }\end{array}$ \\
\hline 5 & $29-31$ & & & $4 \cdot 0$ & $8 \cdot 3-19 \cdot 9$ & $\begin{array}{l}32 \text { somites; } 3 \text { branchial arches clearly } \\
\text { visible; neuropores closed; forelimb } \\
\text { buds recognizable }\end{array}$ \\
\hline 4 & $33-36$ & & & $7 \cdot 0-10$ & $12 \cdot 2-36 \cdot 4$ & $\begin{array}{l}42 \text { somites; deep and broad olfactory pits; } \\
\text { posterior limb buds appear }\end{array}$ \\
\hline 3 & $37-38$ & & & $10-11$ & $35 \cdot 8-56 \cdot 0$ & $\begin{array}{l}\text { Somites less distinct anteriorly; eyes are } \\
\text { defined; fore and hind foot plates formed }\end{array}$ \\
\hline 4 & $39-40$ & & & $11 \cdot 5-13$ & $99 \cdot 0-227$ & $\begin{array}{l}\text { Naso-maxillary fissure closed; prefoot } \\
\text { plate shows digital ridges; umbilical } \\
\text { hernia marked }\end{array}$ \\
\hline 3 & $41-45$ & & & $13-15$ & $251-402$ & $\begin{array}{l}\text { In the anterior limb buds the digits are } \\
\text { separated; the hind foot plate has } \\
\text { differentiated digit rays }\end{array}$ \\
\hline 5 & $50-58$ & & & $18-23$ & $800-1400$ & $\begin{array}{l}\text { Eyelids fused; pinna well developed; } \\
\text { digits clearly defined; umbilical hernia } \\
\text { reduced }\end{array}$ \\
\hline 5 & $60-66$ & & & $21-32$ & $1785-4525$ & Genital tubercle has begun to differentiate \\
\hline 6 & $72-82$ & & & $29-43 \cdot 5$ & $6277-9000$ & $\begin{array}{l}\text { Penis and clitoris differentiated; large } \\
\text { vibrissae; fine hair all over the body; } \\
\text { nipples present }\end{array}$ \\
\hline 4 & $86-90$ & & & $45-50$ & $10000-14000$ & Newborn \\
\hline
\end{tabular}

* After copulation (Day 0).

$\dagger$ After finding spermatozoa in the vaginal smear $(0 \mathrm{~h})$.

At 13-14 days p.c. the embryo was in the floor of the amniotic cavity and consisted of an ectodermal and an endodermal layer (Pl. 1, Figs 5 and 6).

At 19-20 days p.c. the primitive streak had appeared as a thickened linear band in the midline of the dorsal aspect of the embryonic disc, and 1 day later, the mesoderm had developed and three primordial layers were evident (Pl. 1, Fig. 7). 


\section{Somite stage}

At 24 days p.c. the embryos had a neural groove and 4 or 5 pairs of somites (Pl. 1, Figs 8 and 9). The notochord and two endocardial tubes were present.

Embryos of 25-26 days p.c. had 6-20 somites, the neural folds were closing, the endocardial tubes were fusing in the midline and the hindgut began to form.

At 27 days p.c., torsion and flexion were beginning and the embryo was C-shaped (PI. 1, Fig. $10)$. It was connected to the yolk sac by a short and narrow stalk and 20 somites were present. Mandibular and hyoid processes were well developed and maxillary processes were forming on each side of the stomodaeum (Pl. 2, Fig. 11). Ear placodes and eye cups were visible throughout the epidermis (PI. 2, Fig. 12).

There were no limb buds but a small tail bud was present. Internally, the three primary brain vesicles (prosencephalon, mesencephalon and rombencephalon) were present. The neuropores were still open. Most of the somites showed a small myocoele and the notochord had appeared between the gut and the neural tube. The tubular hearts were fused to form a single tubular heart. The ventricular and atrial regions of the heart were delimited and covered by an endocardium and an epimyocardium (Pl. 2, Fig. 13). The dorsal aortae and two aortic arches were present. The foregut and hindgut were developed and the liver bud had appeared.

At 29 days, 32 somites were clearly defined, the embryonic flexure was more accentuated and there was a short tail bud which contained about 7 somites (Pl. 2, Fig. 14). Medial and lateral nasal processes were well developed and were separated by an olfactory pit (Pl. 2, Fig. 15). The third visceral arch had appeared and the mandibular processes were fused in the midline. The anterior limb buds had appeared as a prominent oval projection.

Internally, the neuropores were closed. Telencephalon, diencephalon, mesencephalon, metencephalon and myelencephalon had differentiated and the cranial spinal ganglia were

\section{PLATE 1}

Scale bar $=1 \mathrm{~mm}$; times are given in relation to finding spermatozoa in the vaginal smear $(0 \mathrm{~h})$ or time after copulation, p.c. (Day 0).

Fig. 1. An egg with pronuclei at $24 \mathrm{~h} \times 300$.

Fig. 2. A 2-cell stage recovered from the oviduct at $48 \mathrm{~h} \times 300$.

Fig. 3. Morula recovered from the uterine cavity at $72 \mathrm{~h} \times 300$.

Fig. 4. A section through a blastocyst in the uterine cavity at $6 \frac{1}{2}$ days. $\mathrm{H} \& \mathrm{E}, \times 250$.

Fig. 5. Transverse section through the uterus showing an implanted embryo 13-14 days p.c. Note the bilaminar embryonic disc (thick arrow) and the amniotic cavity (thin arrow). H \& E, $\times 300$.

Fig. 6. Longitudinal section through another implanted embryo from the same pregnancy as in Fig. 5. Observe the amniotic cavity (thin arrow); embryonic disc (thick arrow); extra-embryonic coelom (e) and ectoplacental cavity (arrow head). $\mathrm{H} \& \mathrm{E}, \times 300$.

Fig. 7. Transverse section through a trilaminar embryo 20-21 days p.c. Amnion (thick arrow); intra-embryonic mesoderm (thin arrows); embryonic endoderm (arrow head). Toluidine blue, $\times 500$.

Fig. 8. An embryo (24 days p.c.) with neural groove and 4 somites. Note the allantoic bud (arrow).

Fig. 9. Transverse section of embryo at 24 days p.c. Neural groove (arrow head); amniotic cavity (a); somitic mesoderm (S); intermediate mesoderm (thin arrow); lateral mesoderm (thick arrow). Toluidine blue, $\times 500$.

Fig. 10. Embryo with 20 somites ( 27 days p.c.), showing the characteristic $\mathrm{C}$-shape curvature and a ventral prominence caused mainly by the heart. Two branchial arches are clearly visible and the third is beginning to develop. 

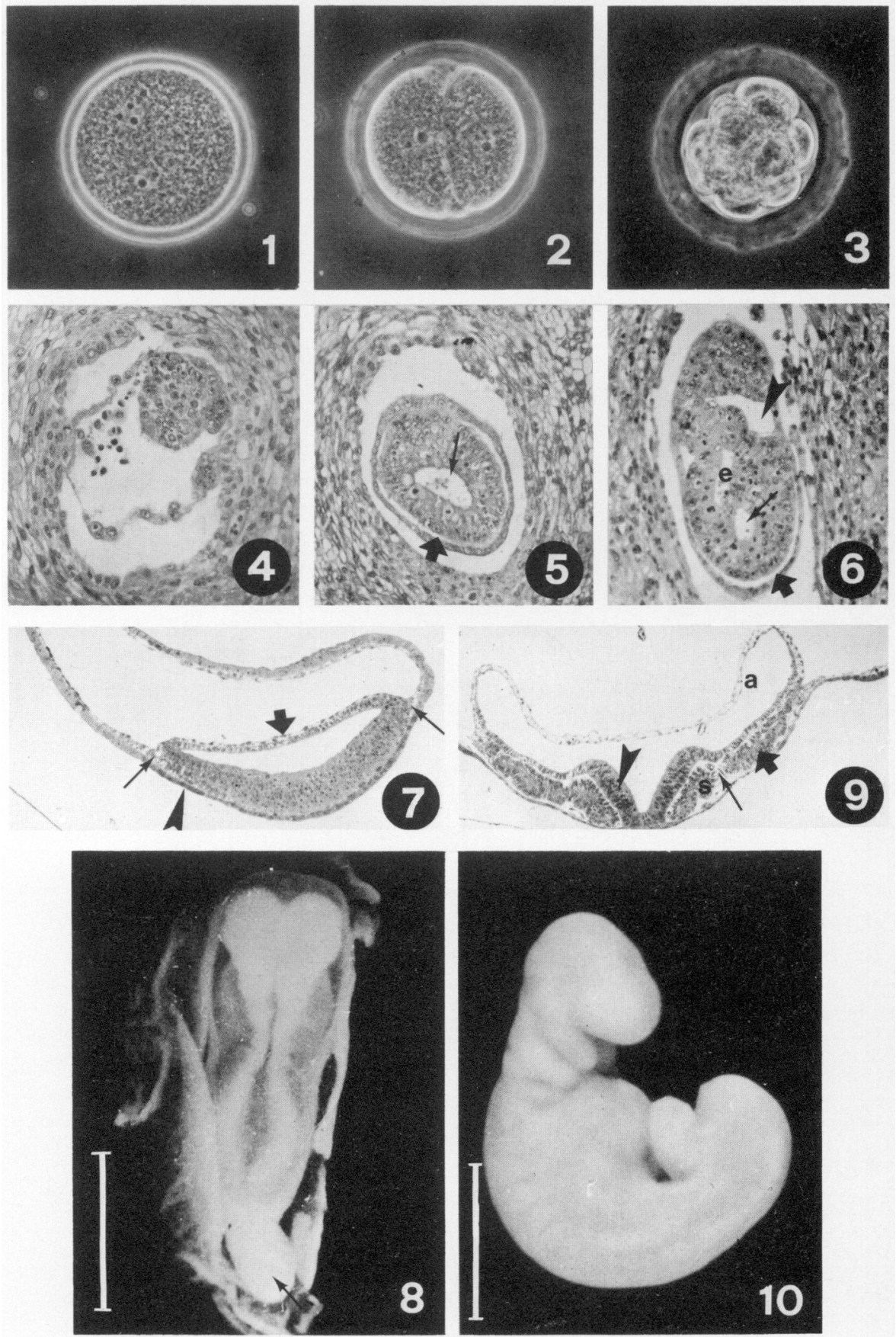
PLATE 2

Scale bar $=1 \mathrm{~mm} ;$ p.c. $=$ time after copulation (Day 0$)$.

Fig. 11. Facial view of a 27-day-old embryo, illustrating the relationship of the stomodaeum (S) with the first branchial arch or mandibular process (thick arrow) and the maxillary (thin arrow) and frontonasal prominences (f). $\times 20$.

Fig. 12. Transverse section through the cranial region of a 27-day-old embryo. Pharynx (p); mandibular process (m); first aortic arch artery (a); aorta (A); otic placode (arrow head); first pharyngeal pouch (thin arrow); first branchial groove (thick arrow). Toluidine blue, $\times 125$.

Fig. 13. Transverse section through the heart region of a 27 -day embryo (same pregnancy as Fig. 12) showing the heart tube suspended by the dorsal mesocardium (arrow head) and the layers of the heart wall: endocardium (thin arrow) and epimyocardium (thick arrow). Foregut (f); dorsal aorta (A); pericardial cavity (p); somites (s). Toluidine blue, $\times 125$.

Fig. 14. Embryo with 32 somites ( 29 days p.c.) showing 3 branchial arches and the prelimb bud.

Fig. 15. Face of a 29-day-old embryo. The nasal pit (arrow head) and medial and lateral nasal prominences are easily recognized. Nasolacrimal groove (arrow); first branchial arch (1); second branchial arch (2). $\times 12$.

Fig. 16. Transverse section through a 29-day-old embryo (4 mm crown-rump length) showing the mesonephric tubules (thick arrow) and mesonephric duct (thin arrow). Dermomyotome (d); mid gut (arrow head); dorsal aorta (A); dorsal mesentery (M); intraembryonic coelom (i). Toluidine blue, $\times 125$.

Fig. 17. Embryo with 42 somites ( 33 days p.c. and $7 \mathrm{~mm}$ crown-rump).

Fig. 18. Photograph of a $10-\mathrm{mm}$ crown-rump embryo (about 37 days p.c.).

Fig. 19. Parasagittal section through the body of a 37-day-old embryo. Stomach (S); dorsal mesentery (thin arrow); mesonephros (m); lung (l); metanephric bud (thick arrow); gonad (g); Wolffian duct (arrow head). PAS-haematoxylin, $\times 125$. 
PLATE 2
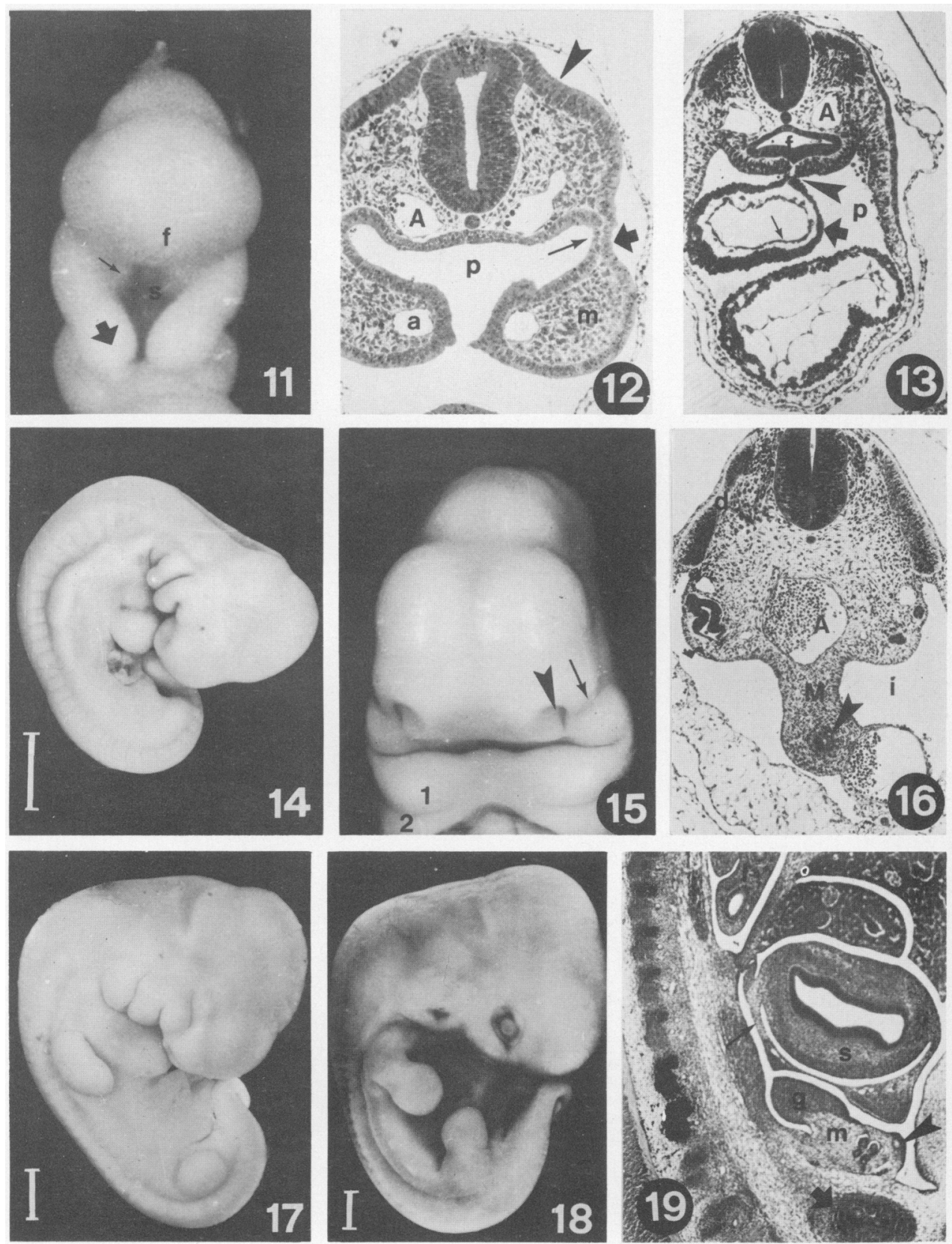
PLATE 3
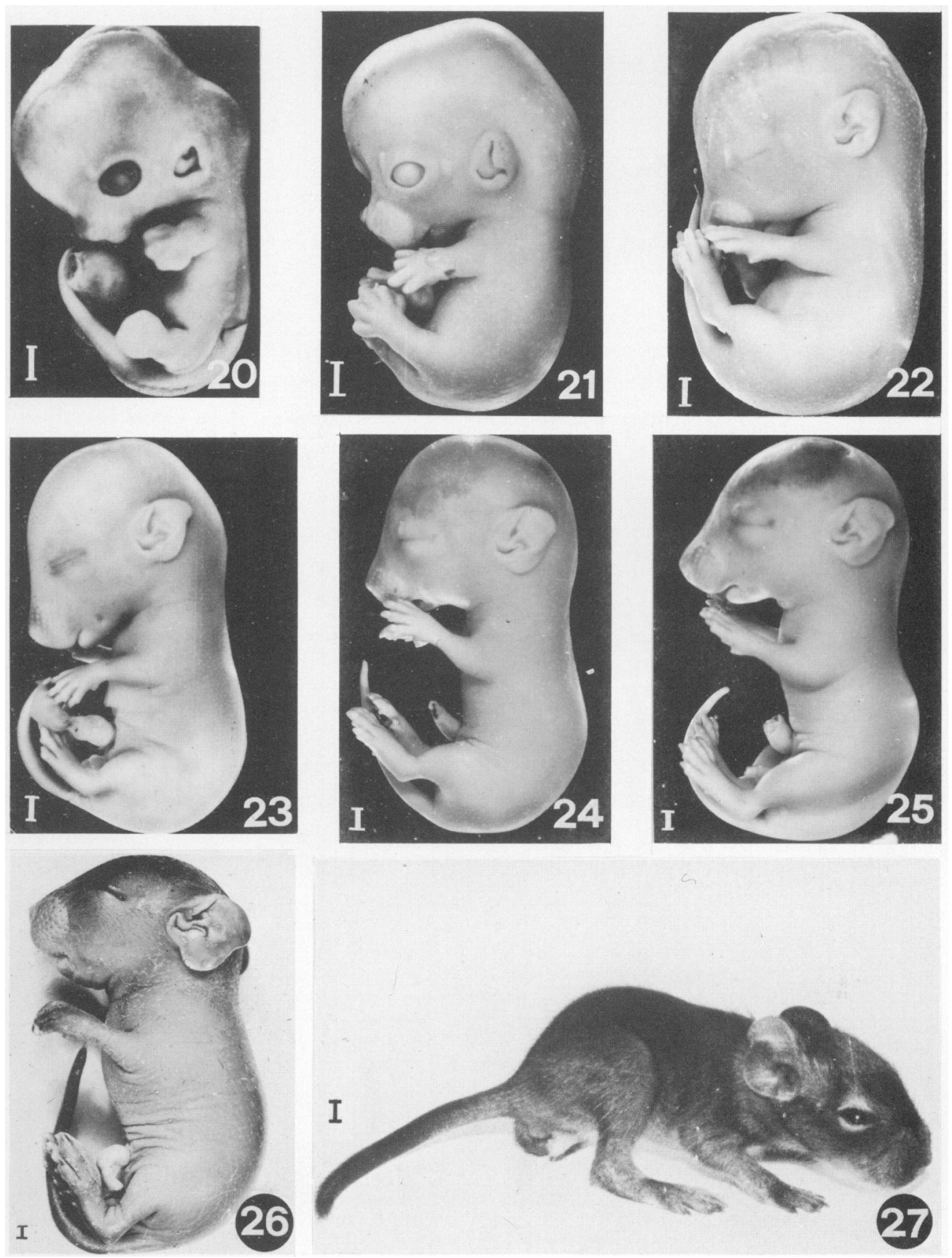
present. The dermomyotome had differentiated in the somites and separated from the sclerotome. Rathke's pouch was present. The mesonephric tubules and mesonephric duct had appeared but no glomeruli were seen (PI. 2, Fig. 16). The pregonadal bud, formed by a coelomic epithelium and mesenchymal tissue, was present in the ventromedial region of the mesonephroi. Primordial germinal cells were migrating.

At 33 days, the olfactory pits were broad and deep and the nasomaxillary cleft was clearly visible throughout its length. There was no noticeable development of a pinna. The posterior limb buds had appeared and the anterior limb buds had enlarged and showed more development ( $\mathrm{Pl}$. 2, Fig. 17). There were no appreciable changes in the gross morphology of the central nervous system at this time. The wall of the neural tube had differentiated into three zones-ependymal layer, mantle layer and marginal zone. The optic cup and lens vesicle were present and the ear vesicles were visible on either side of the rhombencephalon. Partitioning of the atria and ventricles was beginning. Chondrification centres had appeared in some mesenchymal vertebrae. The liver was well developed and prominent. Mesonephric tubules were numerous and well developed. The germinal epithelium was greatly thickened, the primordial germinal cells were beginning to colonize and some cells of the germinal epithelium appeared to be in close contact with them.

\section{Embryos from 37 to 56 days}

At 37 days the somites were less distinct anteriorly but still well defined in the posterior half, including the tail. The maxillary processes were fused with the lateral nasal processes and with the medial nasal and the eyes were clearly defined. The cervical sinus had been obliterated and the external auditory meatus was formed from the first visceral cleft. Hair follicles had appeared on the upper lip, but were few or none on the body and head. Anterior limb buds showed some regional differentiation and the forefoot plates were developed (Pl. 2, Fig. 18). The genital tubercle had appeared on the ventral surface of the body.

The stomach was well developed and a small physiological umbilical hernia was present. The metanephric diverticulum had formed and the cloaca was divided by the urorectal fold. The undifferentiated gonadal blastema was formed by the coelomic epithelium, primary sexual cords and mesenchymal tissue. The testis was distinguishable by its sexual cords in which the gonocytes were in the centre of the cord surrounded by pre-Sertoli cells. The ovary was not yet distinguishable (Pl. 2, Fig. 19).

At 39 days, the eyes were clearly defined and retinal pigment began to appear. The nasomaxillary fissure was closed and there was a pinna bud. The tail had grown in length

\section{PLATE 3}

Scale bar $=2 \mathrm{~mm} ;$ p.c. $=$ time after copulation (Day 0$)$.

Fig. 20. A 13-mm crown-rump embryo (about 39 days p.c.). Note the interdigital notches between the rays in the forefoot plate and the prominence of the proximal portion of the umbilical cord caused by the intestine (umbilical hernia).

Fig. 21. A 41-day-old embryo ( $15 \mathrm{~mm}$ crown-rump). Note the webbed digits in the forefoot and the notches between the hindfoot rays.

Fig. 22. A $18 \mathrm{~mm}$ crown-rump fetus (about 56 days p.c.). The eye lids are fused, the digits are clearly defined; the pinna is well developed and no hair is visible.

Fig. 23. A 61-day-old fetus, $21 \mathrm{~mm}$ crown-rump.

Fig. 24. A 66-day-old fetus, $26 \mathrm{~mm}$ crown-rump.

Fig. 25. A 72-day-old fetus, $29 \mathrm{~mm}$ crown-rump.

Fig. 26. An 80 -day-old fetus, $40 \mathrm{~mm}$ crown-rump. The eyes are beginning to open. Note a supernumerary inguinal nipple.

Fig. 27. A newborn degu (87 days p.c.). 
considerably and was clearly demarcated from the trunk. The front limb plate showed digit rays while the foot plate had differentiated into the posterior limb bud (Pl. 3, Fig. 20). Hair follicles had appeared all over the body and the head.

The umbilical hernia was marked. Pancreas, spleen and cerebellum were developed and the lateral palatine processes were growing vertically on each side of the tongue.

At 41 days the digits had separated in the anterior limb buds and digit rays were visible in the hind-limb buds. Hair follicles were more numerous and the pinna was more developed (Pl. 3, Fig. 21).

The palatine processes were horizontal. The gonad was well developed, but only the testis was differentiated. Müllerian and Wolffian ducts were present.

\section{Fetal stage}

At 56 days, the fetuses had developed the characteristic octodontid features. The eyelids had appeared and fused and the pinna was more developed. The limb buds had lengthened and the umbilical hernia had been reduced (Pl. 3, Fig. 22).

Tooth buds had appeared and the secondary palate was formed. In the male, the Müllerian ducts showed marked degeneration, the lumina being almost obliterated while the Wolffian ducts were well developed.

At 66 days, the eyelids were still fused but the external ears had their final shape. The digits were completely separated and the genital tubercle began to differentiate (Pl. 3, Fig. 23). In the male, the testis was completely differentiated. The ovary was now distinguishable and showed a great proliferation of oogonia and a great number of oocytes in meiotic prophase.

At 72 days, the nasal cavities, hair and nails were visible. The genital tubercle was differentiated into a clitoris or penis (Pl. 3, Fig. 25). The testis contained a great number of Leydig cells and peritubular myoid cells and the Müllerian duct had completely degenerated. In the female, the first primordial follicles in the ovary and the involution of the Wolffian duct were observed.

At 80 days large vibrissae, long stained nails and fine hair all over the body were observed. The nipples were visible, 3 lateral pairs and one inguinal pair (Pl. 3, Fig. 26). Most of the internal organs were completely developed.

At birth the eyes were still shut or half opened and the body was completely covered with guard hairs. The incisors were well developed. The external genitalia were well defined and the vagina was closed in the female (PI. 3, Fig. 27).

\section{Discussion}

Although the degu, like other caviomorph species, exhibits a long pregnancy for its size (Weir, 1974), the developmental stages are similar to those of other mammals. Gruneberg (1943) suggested that the crown-rump length of embryos and fetuses is a poor guide to their gestational age, because artificial deformations can occur very easily when they are transferred into saline or a fixative solution, but our study involved animals at known times after copulation and reasonable numbers of embryos were studied at each stage. Because Scott (1937) reported that the weight, length and state of development are very different in guinea-pig embryos from the same litter, we studied the most advanced member of each litter.

The largest increase in weight and crown-rump length takes place in the fetal period when organogenesis is completed. The weights of embryos and fetuses varies greatly independently of age and crown-rump length and so fetal weight is probably not a useful indicator of gestational age in this species. The degree of development as described in this paper is a more precise measure.

Degu blastocysts were found in the uterine cavity at $96-100$ h p.c., as in the guinea-pig, 
although in myomorphs (rat, mouse, hamster) the blastocysts reach the uterus by $82 \mathrm{~h}$ p.c. (Scott, 1937; Graves, 1945; Otis \& Brent, 1954; Hamilton, 1956; Enders \& Schlafke, 1967).

As in most rodents, implantation was antimesometrial and of the interstitial type (Scott, 1937; Blandau, 1949; Boyer, 1953; Roberts \& Perry, 1974). The time of implantation at $6 \frac{1}{2}-7$ days p.c. (Roberts \& Perry, 1974; present study) is similar to that in some other caviomorphs studied, i.e. 6-7 days in the domestic guinea-pig (Scott, 1937) and in the cuis and casiragua (Roberts \& Perry, 1974), but longer than in myomorphs, i.e. $4 \frac{1}{2}-5$ days in the mouse and hamster (Gruneberg, 1943; Boyer, 1953) and 6 days in the Mongolian gerbil (Bagwell \& Leavitt, 1974).

As in other caviomorphs (Roberts \& Perry, 1974), amniogenesis is produced by cavitation and a complete inversion of germ layers takes place at an early stage of development. The presomitic period ending at 21 days p.c. is longer than those observed in the guinea-pig (Scott, 1937), hamster (Boyer, 1953), mouse (Gruneberg, 1943) and Mongolian gerbil (Bagwell \& Leavitt, 1974), but similar to that of the human Embryo (Otis \& Brent, 1954).

The periods of somitic development and organogenesis are similar in pattern to those of other rodents but take longer, as would be expected from the longer total gestation period (Roberts, 1970; Roberts \& Perry, 1974).

The embryonic development of the degu does not have any unusual features of development compared with that of other caviomorphs and a near relative Spalacopus cyanus (Unda, Rojas \& Yañez, 1980). However, the evolution of the germinal line in the male reaches the spermatogonium stage in the fetal period (Morales \& Leyton, 1977). This event has only been observed in the ram (Gondos, 1977) and men (Gondos \& Hobel, 1971) because in numerous animals the differentiation of the germinal line is stopped at the gonocyte stage and complete maturation takes place in the post-natal life (Gondos, 1977).

Despite the slow rate of growth of the embryos, particularly in the early stages of pregnancy, the degu has one of the shorter gestation lengths compared to other caviomorph species. It could be correlated with its greater litter size. Moreover, the ratio of neonatal weight to adult body weight is greater than in most other caviomorphs studied (Kleiman, Eisenberg \& Maliniak, 1980).

It is the extended pattern of development that suggests that the degu might be useful for particular types of developmental study.

We thank $\mathrm{Mr}$ O. Valladares for technical assistance; and Dr Claudio Barros, Dr E. Bustos-Obregón, Dr J. Arrau and Dr D. Lemus for criticism of the manuscript.

This work was supported by Grant 1219-811-5 from the Servicio de Desarrollo Cientifico y de Cooperacion Internacional of the University of Chile and with funds from the Department of Experimental Morphology, Medical School, University of Chile.

\section{References}

Bagwell, J.N. \& Leavitt, W.W. (1974) Prenatal size-age relationships and external morphology in the Mongolian gerbil (Meriones unguiculatus). Am. J. Anat. 140, 117-127.

Berrios, M., Flechón, J.E. \& Barros, C. (1978) Ultrastructure of Octodon degus spermatozoon with special reference to the acrosome. J. Anat. 151, 39-54.

Blandau, R. (1949) Observations on implantation of the guinea-pig ovum. Anat. Rec. 103, 19-48.

Boyer, C. (1953) Chronology of development for the golden hamster. J. Morph. 92, 1-38.
Brinster, R.L. (1971) Mammalian embryo metabolism. In The Biology of the Blastocyst, pp. 303-307. Ed. R. J. Blandau. University of Chicago Press, Chicago.

Contreras, L. \& Bustos, E. (1977) Ciclo reproductivo anual en Octodon degus (Molina) macho. Medio Ambiente 3, 83-90.

Contreras, L. \& Bustos-Obregón, E. (1980) Anatomy of reproductive tract in Octodon degus Molina: a nonscrotal rodent. Arch. Androl. 4, 115-124.

Enders, A. \& Schlafke, S. (1967) A morphological analysis of the early implantation stages in the rat. Am. J. Anat. 120, 185-226. 
Gondos, B. (1977) Testicular development. In The Testis, pp. 1-37. Eds A. D. Johnson \& W. R. Gomes. Academic Press, New York.

Gondos, B. \& Hobel, C. J. (1971) Ultrastructure of germ cell development in the human fetal testis. $Z$. Zellforsch. mikrosk. Anat. 119, 1-12.

Graves, P.A. (1945) Development of the golden hamster Cricetus auratus Waterhouse, during the first nine days. Am. J. Anat. 77, 219-251.

Gruneberg, H. (1943) The development of some external features in mouse embryos. J. Hered. 34, 89-92.

Hamilton, W.J. (1956) The early development of the golden hamster (Cricetus auratus). J. Anat. 90, 395-416.

Kleiman, D.G., Eisenberg, J.F. \& Maliniak, E. (1980) Reproductive parameters and productivity of Caviomorph rodents. In Vertebrate Ecology in the Northern Neotropics, pp. 173-183. Ed. J. F. Eisenberg. Smithsonian Institution Press, Washington, D.C.

Montenegro, M.A., Bustos, S., Berríos, M. \& Barros, C. (1977) Activación $y$ reacción del acrosoma del espermatozoide de Octodon degus. Medio Ambiente 3, 120-126.

Montenegro, G., Hoffmann, A., Aljaro, M.E. \& Hoffmann, A.E. (1979) Satureja gilliesii, a poikilohydric shrub from the Chilean mediterranean vegetation. Can. J. Bot. 57, 1206-1213.

Morales, B. \& Leyton, V. (1977) Desarrollo pre y post natal del testiculo de Octodon degus (Molina). Medio Ambiente 3, 91-99.

Morales, B., Leyton, V. \& Rojas, M.A. (1978) Ultraestructura del epitelio celómico durante la diferenciación testicular en Octodon degus (Molina). Rev. Micr. Electr. 5. 140-141.

Osgood, W.H. (1943) The mammals of Chile. Publs Field Mus. nat. Hist. (Zool.) 30, 108-110.
Otis, E.M. \& Brent, R. (1954) Equivalent ages in mouse and human embryos. Anat. Rec. 120, 33-64.

Potocnjak, P. \& Bustos-Obregón, E. (1977) Espermato génesis y duración del ciclo del epitelio seminifero en Octodon degus Molina. Medio Ambiente 3, 100-111.

Roberts, C.M. (1971) The early development of some hystricomorph rodents with particular reference to Chinchilla laniger. J. Reprod. Fert. 27, 488-489.

Roberts, C.M. \& Persy, J.S. (1974) Hystricomorph embryology. Symp. zool. Soc. Lond. 34, 333-360.

Rojas, M., Rivera, O., Montenegro, G. \& Barros, C. (1977) Algunas observaciones en la reproducción de la hembra silvestre de Octodon degus, Molina y su relación con la fenologia de la vegetación. Medio Ambiente 3, 78-82.

Scott, J.D. (1937) The embryology of the guinea-pig. $J$. Anat. 60, 397-432.

Tamayo, M. \& Frassinetti, D. (1980) Catálogo de los mamiferos fósiles y vivientes de Chile. Bol. Mus. Nac. Hist. Nat. Chile 37, 323-399.

Unda, C., Rojas, M.A. \& Yañez, J. (1980) Estudio preliminar del ciclo reproductivo y efecto medio ambiental en dos poblaciones de Spalacopus cyanus (Molina). Proc. 23rd Ann. Meet. Soc. Biol. Chile, p. 115, Abstr.

Weir, B.J. (1970) The management and breeding of some more hystricomorph rodents. Lab. Anim. 4, 83-97.

Weir, B.J. (1974) Reproductive characteristics of hystricomorph rodents. Symp. zool. Soc. Lond. 34, 265-301.

Weir, B.J. \& Rowlands, I.W. (1974) Functional anatomy of the hystricomorph ovary. Symp. zool. Soc. Lond. 34, 303-332.

Yañez, J. \& Jaksic, F. (1978) Historia natural de Octodon degus (Molina) (Rodentia, octodontidae). Rev. mus. nac. Hist. Nat. Chile 27, 3-11.

Received 19 August 1981 